\title{
PERANCANGAN SOLAR CELL SEBAGAI SUMBER ENERGI LISTRIK ALTERNATIF UNTUK PENERANGAN LOBBY FAKULTAS TEKNIK UNRIKA
}

\author{
Roma Gustiawan $^{1}$, Endang Susanti ${ }^{2}$, Pamor Gunoto ${ }^{3}$ \\ ${ }^{1,2,3)}$ Teknik Elektro, Fakultas Teknik, Universitas Riau Kepulauan \\ Email : endang_unrika@yahoo.co.id
}

\begin{abstract}
Electricity is one of the most important needs of the community electricity shorttages are very disturbing human activities as well as the University of Riau Islands campus is very dependent on electricity supply from PLN, because this campus conducts tearning activities at night, the current energy is mustly fulfilled by fosil fuel energy such as petroleum, coal and natural gas but the supply of this energie is decreasing, PLN which as a supply of electricity is very dependent on fossil fuels so that PLN can at any time turn out blackouts on the campus of the University of Riau Islands very disturbed with the rilling blackout because the campus will be dark.there needs to be alternative energy at least illuminating as long as the electricity from PLN is on, this research and design is to build asolar electricity supply sistem to help temporary lighting in this design. PLTS is utilized as Alternative electrical energy to illuminatethe lobby of the Faculty of engineering Universitas Riau.

Byusing 50Wp solar cell panel,charge controller to maintain the stability of the sistem and 42 Ah batrtery, by using this sistem Dc lamps as a load of 54 Watt batrei capacitycan be lit during a blackout from the PLN.
\end{abstract}

Keywords: Alternative Energy, PLTS With DC load

\begin{abstract}
ABSTRAK
Energi listrik merupakan salah satu kebutuhan masarakat yang sangat penting kekurangan energi listrik sangat lah menggangu aktifitas manusia begitu juga kampus Universitas Riau Kepulauan sangat tergantung dengan pasokan listrik dari PLN, karena kampus ini melakukan kegiatan belajarmengajar dimalam hari, Energi yang ada saat ini sebagian besar terpenuhi oleh energy bahan bakar fosil seperti minyak bumi, Batu Bara dan gas alam namun persedian energy ini semakin berkurang ,PLN yang sebagai penyediaan energy listrik sangat lah tergantung dengan bahan bakar fosil sehingga PLN sewaktu-waktu bisa melakukan pemadaman bergilir kampus Universitas Riau Kepulauan sangat terganggu dengan Pemadaman Bergilir Tersebut Karna kampus akan gelap.

Dengan mengunakan Panel Solar Cell 50Wp, Charge Controller untuk menjaga kestabilan system dan batrei $42 \mathrm{Ah}$, dengan menggunakan system ini lampu dc sebagai beban dari Batrei yang berkapasitas 54 Watt dapat menyala selama pemadaman dari PLN terjadi.
\end{abstract}

Kata Kunci: Energi Alternatif ,PLTS dengan beban DC 


\section{Pendahuluan}

Kota Industri adalah salah satu Kota yang pengguna Energi yang sangat besar. Batam adalah salah satu termasuk dalam Kategori Kota Industri yang tidak bisa dipungkiri menggunakan Energi sangat besar juga termasuk Energi Listrik khusus nya. Kebutuhan Energi yang terus meningkat sebagai laju pertumbuhan pembangunan dan semakin menipisnya cadangan Minyak Bumi memaksa manusia untuk mencari sumber Energi Alternative, Energi yang ada saat ini sebagian besar terpenuhi oleh Energi bahan bakar Fosil seperti Minyak Bumi, Batu Bara, dan Gas Alam, namun persediaan Energi saat ini semakin berkurang, jika tidak segera ditangani kemungkinan tak terhindarkan lagi adanya krisis energi.[1]

Universitas Riau Kepulauan misalnya. Jika PLN melakukan Program pemadamam bergilir ini sangat menggangu bagi mahsiswa di Universitas Riau Kepulauan ini untuk melakukan kegiatan belajar mengajar maka dibutuhkan Sumber Energi Listrik yang baru setidaknya bisa Mengkoper penyedian Energi Listrik selama pemadaman bergilir yang dilakukan oleh $P L N$.

Dari Uraian diatas penulis tertarik meneliti dan menggakan tema penengan Solar Ceel sebagai sumber Energi Alternative untuk peneranggan lobby Fakultas teknik Universitas Kepulauan Riau selama 3 jam sampai 4 jam karena sumber energy dari sinar matahari bebas di manfaatkan di saat siang dengan panel Solar cell energy matahari bias di simpan.

\section{Tinjauan Pustaka}

Matahari adalah salah satu yang mensuplai semua panas dan cahaya yang diterima bumi untuk digunakan oleh mahluk hidup, Energi Surya yang jatuh ke bumi dalam bentuk paket paket Energi yang disebut Proton, sel surya didefenisikan sebagai teknologi yang menghasilkan Listrik $D C$ dari suatu bahan Semikonduktor ketika dipaparkan oleh cahaya selama bahan Semikonduktor tersebut dipaparkan oleh cahaya maka Sel Surya akan selalu menghasilkan Energi Listrik, dan ketika tidak dipaparkan oleh cahaya sel surya berhenti menghasilkan energi listrik. Sel Fotovoltaik Surya adalah Semi Konduktor dimana radiasi surya dari pita gelombang tertentu langsung diubah menjadi Listrik, material yang sering digunakan adalah Silicon Kristal apa bila lapisan tipis Silicon dari jenis - $p$ dan jenis $-n$ digabungkan akan terjadi sel sambung $p-n$ ( $p-n$ junction cell) dengan muatan Listrik Statik pada sambungan tersebut Silicon jenis $-p$ kaya muatan positif dengan silicon jenis $-n$ memiliki kelebihan electron [4].

\section{Landasan Teori}

Dalam bab ini, dideskripsikan landasan teori tentang komponen yang berhubunggan dengan rancangan "pembangkit Listrik Tenaga Surya untuk penerangan Lobby Kampus Teknik Universitas Riau Kepulauan" agar lebih spesifik sesuai penelitian yang akan dilakukan.

\section{A. Sel Surya}

Sel Surya adalah peralatan yang Mengkorversi Energi matahari menjadi Energi Listrik Arus searah (Direct Current) bentuk sel surya yang paling umum didasarkan pada Efek photovoltaic $(P V)^{[3]}$

Perbedaan utama dari solar cell panel adalah bahan produksi dari solar cells panel. Bahan solar cells panel yang paling umum adalah crystalline silicon, bahan cristaline dapat terdiri dari single crystal, mono atau single - crystalline, dan poly atau multicristaline. Selain itu solar cell panel ada terbuat dari lapisan tipis Amorphous Silicon. Sel cristaline silicon mempunyai 2 tipe yang hampir serupa meskipun sel single cristaline lebih efisien di bandingkan kan dengan poly cristaline karena poky - cristaline merupakan ikatan antara sel-sel. Keuntungan dari amorphous silicon adalah harga yang terjangkau tetapi tidak seefisien crystalline silicon solar cell.[2] 


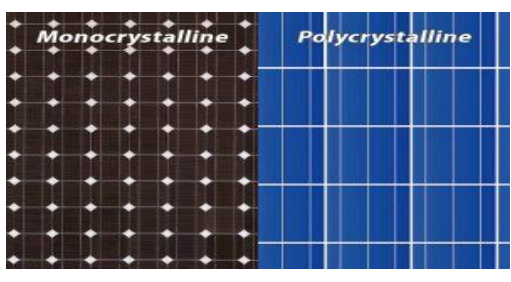

Gambar 2.4 Sel Surya Monocristallined dan Polycystaline $^{[1]}$

Elektroda yang terdiri dari endapan yang sangat tipis dipasang dilapisan permukaan. Sinar surya dalam batas frekuensi gelombang diperlukan untuk menghasilkan electron. untuk itu elektroda pada permukaan ini dibuat sedemikian rupa sehingga tidak menggangu sinar surya yang menimpa nya, dibagian atas lapisan permukaan terdapat bahan transfaran yang kuat dan elastis, elektroda pada wafer disambungkan ke wafer oleh bahan penghantar biasa apa bila sinar surya menimpa sel surya sebagian dari foton akan memberikan tenaganya pada sel tersebut. [2]

Karakteristik yang dibuat berdasarkan panel sel surya $100 \mathrm{Wp}$ adalah sel surya yang memiliki makximum power $\left(P_{\max }\right)$ sebesar $100 w$, maksimum power voltage (Vmp) sebesar $17.6 \mathrm{~V}$, short circuit current $\left(I_{m p}\right)$ Sebesar 4.26 A, open circuit voltage (Voc) sebesar 21,6 V, short circuit current (Isc) sebesar $4.69 \mathrm{~A}^{[3]}$

\section{B. Baterai}

Baterai adalah perangkat yang dapat mengubah energi kimia langsung menjadi energi listrik sebagai tenaga pengerak komponen komponen listrik seperti penerangan (lampu), klakson dan lain lain baterai sangat penting memasok energi keseluruh komponen kelistrikan terutama berarus DC, baterai atau Akumulator adalah sebuah sel listrik dimana didalam nya berlangsung proses elektrokimia yang reversible (dapat berkebalikan) dengan efesiensi nya yang tinggi yang dimaksud dengan reaksi elektrokimia reversible adalah didalam baterai terdapat proses pengubahan kimia menjadi tenaga listrik dan sebaliknya dimana proses tenaga listrik menjadi tenaga kimia dengan cara proses regenerasi dari elektroda - elektroda yang dipakai yaitu dengan melewatkan energi listrik dalam arah polaritas yang berlawanan dalam sel baterai menghasilkan listrik dalam proses kimia. ${ }^{[2]}$

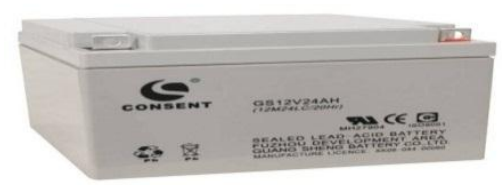

Gambar 2.10 Barterai Lead Acid (Accu)[1]

jumlah maksimum muatan listrik yang dapat ditampung oleh baterai tersebut kapasitas baterai dapat dinyatakan dengan persamaan diawah ini :

$\mathrm{Ah}=$ kuat arus (ampere) $\mathrm{x}$ Waktu (hours)Ah=Ix T...............................2.1[7]

Dimana :

$$
\begin{array}{ll}
\mathrm{Ah} & =\text { Kapasitas baterai /aki } \\
\mathrm{I} & =\text { Kuat arus (ampere) } \\
\mathrm{V} & =\text { Tegangan (Volt) } \\
\mathrm{T} & =\text { Waktu (jam /sekon) }
\end{array}
$$

\section{Lampu DC}

Seperti yang kita ketahui arus DC adalah arus searah sedangkan listrik PLN dirumah mengunakan arus AC (arus bolak balik) sistim penerangan atau lampu dirumah pun juga mengunakan lampu listrik AC karena mudah didapatkan dam bisalangsung dipasang. Tetapi lampu jenis lampu AC mengkonsumsi daya yang lebih banyak dibanding lampu DC yang terbuat dari $L E D$, lampu $L E D 5$ watt setara dengan 14 watt lampu $A C$.

\section{Solar Charge Controller}

Solar charge controller adalah peralatan elektronik yang mengatur aliran arus listrik dari modul surya ke baterai dan beban Charge Controller menjaga baterai tetap terisi penuh tanpa berlebihan (over charge) ketika beban sedang menarik daya, solar Charge Controller memungkinkan arus listrik mengalir dari modul ke baterai. Ketika pengontrol menyensor bahwa baterai terisi penuh maka Solar Charge Controller akan menghentikan aliran arus dari modul solar cell 
panel.[6]

\section{E. Prinsip Dasar Perhitungan Daya Listrik}

Besar nya beda potensial, kuat arus listrik dan lama nya arus mengalir berbanding lurus dengan besar nya energi listrik yang di ubah menjadi energi kalor hubungan ini dapat ditulis dengan secara sistemmatis yaitu:

$W=V I t \ldots \ldots \ldots \ldots \ldots \ldots \ldots \ldots . .2 .3^{[8]}$

Dimana:

$\mathrm{W}=$ Energy listrik yang diubah menjadi energy kalor (joule)

$\mathrm{V}=$ Beda potensial LIstrik (Volt)

$I=$ Kuat arus Listrik (ampere)

$\mathrm{t}=$ lama aliran arus listrik (sekon)

Jika mengunakan hukum Ohm:

$P=V . I$

Untuk mencari rata tata dari Arus dan Teganggan dapatdi hitung dengan persamaan sebagai berikut:

Spercobaan

$$
\text { Rata-rata (r) = Arus (I)total / }
$$

Dapat dilihat untuk penentuan daya listrik tidak memerlukan besaran waktu sehingga lebih mudah dalam perhitungan sehari-hari. Sementara untuk perhitunggan lama pemakain batrei dan perhitungan berapa lama charge controller mengisi batrei dapat juga dilihat dari persamaan sebagai berikut:

Berdasarkan pemafaran factor - factor yang mempengaruhi energi yang di bangkitkan oleh panel surya besar nya panel surya yang dibutuhkan dalam satu rancangan system PLTS dapat dihitung mengunakan persamaan sebagai berikut[3]:

$$
\left.\mathrm{I}_{\text {TOTAL PANEL }}=\mathrm{I}_{\text {TOTAL BEBAN }} \mathrm{X} 1.20\right) /
$$

ESH. $2.15[5]$

Dan nilai ESH adalah Equivalent sun Hous

Besar nya daya kebutuhan panel yang akan dibangkitkan (Pwp) maka banyak nya panel surya yang akan dihitung dapat menggunakan persamaan sebagai berikut[3] Jumlah panel surya $=\mathrm{P}_{\mathrm{wp}} / \mathrm{P}_{\mathrm{mpp}}$ Di mana :

$\mathrm{P}_{\mathrm{MPP}}=$ Teganggan keluar panel surya

Kapasitas batrei yang di butuhkan dapat di hitung dengan menggunakan persamaan sebagai berikut:

$\mathrm{Ah}=\mathrm{E}_{\mathrm{L}} /(\%$ mak DOD $) \mathrm{x}(\mathrm{TCF}) \mathrm{x} \mathrm{V}_{\text {batre }} \mathrm{x}$
AD.

$2.17[5]$

Dimana :

$$
\begin{aligned}
\mathrm{E}_{\mathrm{L}} & =\text { Energi Listrik } \\
\mathrm{DOD} & =\text { Depth of Discharge } \\
\mathrm{TCF} & =\text { Temperature Correction Factor } \\
\mathrm{AD} & =\text { Atonomis Day }
\end{aligned}
$$

Dan kapasitas pengunaan batrei dapat menggunakan persamaan berikut:

$$
\begin{aligned}
& \mathrm{Ah}=\mathrm{E}_{\text {baterai }} / \mathrm{V}_{\text {baterai }} \ldots \ldots \ldots \ldots 2.18^{[5]} \\
& \mathrm{Ah}_{\text {pemakain }} \mathrm{Ah}_{\text {beban }} / \text { Beban................. } 2.19^{[5]} \\
& \mathrm{Ah} \text { Pemakain } \mathrm{X} 20 \ldots \ldots \ldots \ldots \ldots \ldots \ldots \ldots \ldots .2 .20^{[5]}
\end{aligned}
$$

Sedangkan untuk perhitunggan Charge Controller dapat Menggunakan persamaan sebagai Berikut:

$\mathrm{I}_{\text {Max }}=\mathrm{P}_{\text {Max }} /$ Vs.................2.2. $1^{[5]}$

Waktu ( $\mathrm{t})=\mathrm{E}_{\text {pemakain }}$, Rata -rata (r) Solar Cell. $2.22^{[5]}$

\section{Perancangan Sistem dan Pembuatan Alat}

Diagram flow cahrt dari stematik kerja PLTS

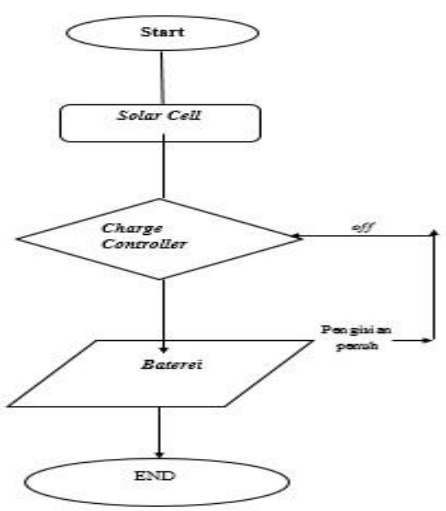

Gambar 3.3 Flow Cahrt dari System kerja Solar Cell

\section{Hasil Dan Pembahasan}

Mengacu pada metodologi penelitian, untuk memudahkan pembuatan dan perancangan alat, maka alat dibagi menjadi beberapa blok bagian kemudian alat dirancang berdasarkan block yang sudah disusun tersebut dan kemudian untuk analisa dan pengukuran metode yang digunakan mengikuti ${ }^{b l o k}$ diagram yang sudah disusun tersebut sehingga pengukuran dilakukan pada setiap block dan secara sisteimatis. 


\section{A. Pengujian pada alat}

Bagian-bagian alat yang di ukur adalah :

1. Panel Solar Cell

2. Batrei

Bagian-bagian rangkaian yang di tes poin adalah:

1. Charger Controller

2. Out put Baterai setelah di gunakan oleh lampu DC

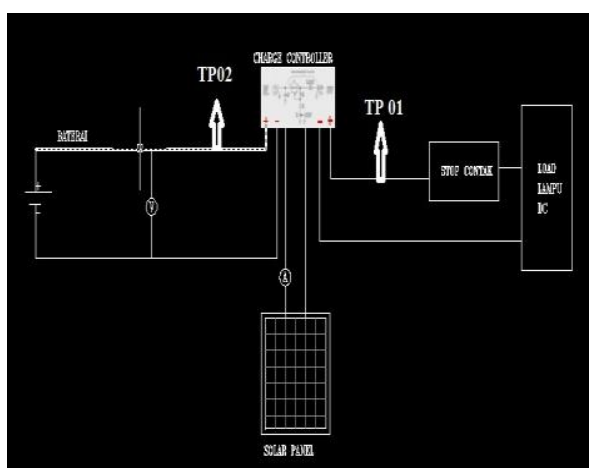

Keterangan

Gambar 4.1 = Block Panel Solar Cell yang akan diambil data nya

Gambar $4.2=$ Batrei yang akan diambil data nya output dan input dari batrei

Gambar $4.3=$ Tes Point 1 atau TP 01

Tes point 2 atau TP 02

\section{B. Pengetesan Panel Solar Cell}

Dari tabel 4.2 di bawah ini akan dijabarkan data hasil pengukuran pada arus dan tegangan yang dihasilkan oleh Solar Cell dari jam 7.00 pagi sampai jam 17.00 sore dan kemudian di analisa dan dibandingkan dengan berapa lama waktu yang di butuhkan Panel Surya untuk mengisi batrei adapun grafik yang di buat adalah sebagai berikut :

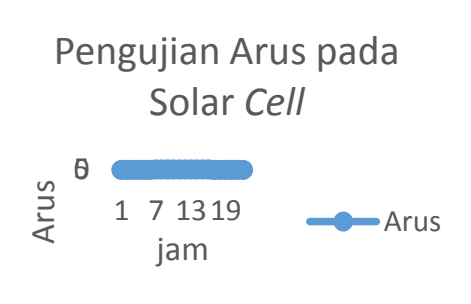

Grafik 4.1 Pembandingan antara Waktu Pengujian terhadap Arus

\section{Pengujian Pada Charge Controller}

Dari tabel 4.2 di bawah ini akan dijabarkan data hasil pengukuran pada arus dan tegangan yang dihasilkan oleh Charge Controllerr dari jam 7.00 pagi sampai jam 17.00 sore dan kemudian di analisa dan dibandingkan dengan berapa lama waktu yang di butuhkan Charge controler untuk mengisi batrei adapun grafik yang di buat adalah sebagai berikut :

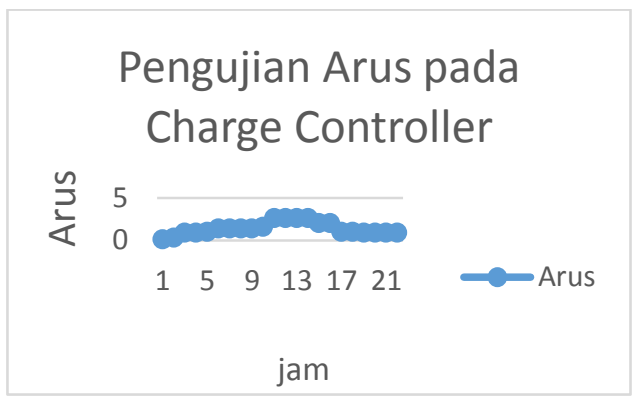

Grafik 4.2 Pembandingan antara Waktu Pengujian terhadap Arus

\section{Pengujian Pada Baterai}

Untuk Pengujian pada batrei disaat batrei dihubungkan dengan beban DC atau lampu LED $54^{\text {watt }}$ dan di mana pada Output diukur Tegangan dan Arus yang dihasilkan oleh rangkaian dan dilakukan pengujian selama 3 jam sampai 4 jam dan diambil data nya sebagai berikut :

\begin{tabular}{|l|l|l|}
\hline Jam & nama & keterangan \\
\hline 08.00 & 12.3 Volt & $42 \mathrm{Ah}$ \\
\hline 09.00 & 12 Volt & $38 \mathrm{Ah}$ \\
\hline 10.00 & 12 Volt & $34 \mathrm{Ah}$ \\
\hline 11.00 & 12. Volt & $34 \mathrm{Ah}$ \\
& & \\
\hline
\end{tabular}

Berdasarkan hasi penggukuran dapat di buat grafik sebagai aberikut: 
Pengujian pemakaian

\section{Batrei Terhadap Beban}

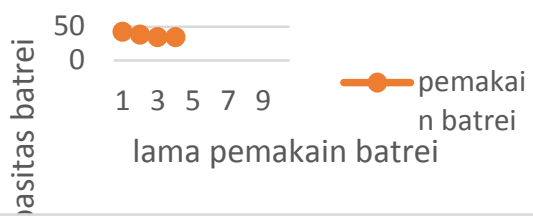

Grafik 4.3 Brafik Pengujian Pada Batrei Terhadap Beban

Dari data di atas, untuk menghitung berapa lama pengisian pada batrei dapat mengunakan rumus pada persamaan dan tabel di atas yaitu:

Beban 1 buah lampu Dc $18 \times 3=54$ watt = $(1 \times 18=18$ watt $)$

Dengan mengunakan Persamaan 2.11

$\mathrm{I}=\mathrm{P} / \mathrm{V} \ldots$

$(18$ watt $/ 12$ volt $=1.5)$

$1.5 \times 3=1.5 \times 3$

I total

$=4.5 \mathrm{~A}$

Total pemakaian lampu adalah:

$$
4.5 \mathrm{~A} / 12^{\text {volt }}
$$

Berdasarkan table di atas dapat dihitung rata- rata pengisian Charge Controller adalah sebagai berikut:

Denganmengunakan Persamaan 2.13

Rata - Rata $(\mathrm{r})=\Sigma$ I total $/ \Sigma$ banyak percobaan $=27.4$ Ampere $/ 20$

(r) = 1,37 Ampere pada suhu

Berdasarkan table di atas dapat dihitung pemakain batrei selama 4 jam adalah $10 A h$. Berdasar data diatas untuk menghitung berapa lama pengisian batrei dapat mengunakan Persamaan 2.18 sebagai berikut:

$\mathrm{T}=\mathrm{I}$ batrei / I Solar Cell $\mathrm{T}=10$ Ah / 1.37 Ampere

$\mathrm{T}=7.2$ jadi $7,2 \times 60$ menit $=432$ menit
Dari hasil perhitungan diatas dapat diambil kesimpulan bahwa batrei dalam keadan sudah digunakan beban untuk pengisian kembali oleh Charge Controller adalah mmengunakan waktu 7 jam,12 menit batrei kondisi penuh kembali.

\section{Kesimpulan}

Berdasarkan penelitian dan perancangan yang penulis lakuakan, maka dapat penulis ambil kesimpulan mengenai Perancangan Solar Cell Sebagai Sumber Alternatif untuk Penerangan Lobby Fakultas Teknik Unipersitas Riau Kepulauan sebagai berikut:

Energi listrik dari Solar Cell bisa
dijadikan energi alternative dengan
menyimpan energi dengan mengunakan
batrei,dengan memanfaatkan Sinar matahari,sinar matahari yang masuk ke panel Solar Cell Akan menimbulkan energy listrik.Pada aplikasi ini dengan memanfaatkan energy listrik dari solar Cell dan di transfer ke batrei, dan beban yang di gunakan adalah lampu $L E D$ atau Lampu DC maka rangkaian ini hanya membutuhkan sebuh rangkaian Charge Controller yang berfungsi sebagai pengotrol arus masuk dari Solar Cell dan Arus keluar dari batrei.

Untuk pengisian batrei dilihat dari daya yang dihasilkan oleh Solar Cell dalam perancangan ini batrei dapat terisi lama 7 jam 2 menit, dan lama waktu lampu meyala 1 sampai 4 jam.

\section{DAFTAR PUSTAKA}

[1] Analisa rancangan sel surya dengan kapasitas 50 watt untuk penerangan parker unista. $2016 \mathrm{http}: / /$ www ejurnal undip.ac.id [4/04/2019]

[2] Analisa rancangan lampu LED di dalam rumah http://www. tejo sutedi .ac.id [4/04/2019]

[3] Pengisian baterai hanpon dengan mengunakan Solar Cell. 2014 
http;//www.repository.ac.id

[04/04.2019]

[4] Rancangan bangunan penyedian energy listrik (PLTS) untuk membantu pasokan rumah tangga. 2018http:// www jurnal heri haryanto [5/04/2019]

[5] Su, Supranto Prof.dr.ir.h Teknologi Tenaga Surya. Penerbit Prediya Paramida, Jakarta, 2005

[6] Supradi toni, Komponen rangkaian Elektronika penerbit Kata pena , Jakarta 2015,

[7] Klian Delman, Modern Control Teknologi Componen And Sistem, Hand Book, Mega Engineering,Inc Stamford 1999

[8] Wibowo tedi, Inspirasi sais Energi dan Perubahan nya penerbit Ganeca Exact jakarta april 2015 